\title{
Algengi og áhættupættir lengdrar dvalar á gjörgæsludeild eftir kransæðahjáveituaðgerð
}

\section{Erla Liu Ting Gunnarsdóttir ${ }^{1}$}

\section{Sunna Lu Xi Gunnarsdóttir ${ }^{1}$ \\ Alexandra Aldís Heimisdóttir ${ }^{1}$}

Sunna Rún Heiðarsdóttir ${ }^{1}$

Sólveig Helgadóttir ${ }^{2}$

Tómas Guðbjartsson ${ }^{1,3}$

Martin Ingi Sigurðsson ${ }^{1,4}$

${ }^{1}$ Læknadeild Háskóla Íslands, ${ }^{2}$ svæfinga- og gjörgæsludeild Akademíska sjúkrahússins í Uppsölum í Svípjóð, ${ }^{3}$ hjarta- og lungnaskurðdeild, ${ }^{4}$ svæfinga- og gjörgæsludeild Landspítala.

Höfundar eru læknanemar við læknadeild Háskóla Íslands nema Martin Ingi Sigurðsson, Tómas Guðbjartsson og Sólveig Helgadóttir sem eru læknar.

Fyrirspurnum svarar Martin Ingi Sigurðsson, martiningi@gmail.com

\section{Inngangur}

Á Íslandi eru gerðar 100-150 kransæðahjáveituaðgerðir á ári. Fyrstu nóttina eftir aðgerð hafa allir sjúklingar hingað til dvalist á gjörgæsludeild til eftirlits. Sumir sjúklingar purfa pó lengri dvöl vegna umfangsmeiri gjörgæslumeðferðar eftir aðgerðina eða fylgikvilla. Á Landspítala eru tvær gjörgæsludeildir sem rúma alls 22 sjúklinga, en undanfarin tvö ár hefur ekki verið unnt að nýta nema 12-13 pláss vegna skorts á hjúkrunarfræðingum. Á sama tíma hefur bæði sjúklingum og legudögum á gjörgæsludeildinni fjölgað, einkum vegna bráðainnlagna, sem getur valdið pví að valkvæðum gjörgæsluinnlögnum er frestað. ${ }^{1}$ Árið 2018 var rúmlega priðjungi allra hjartaaðgerða frestað vegna plássleysis á gjörgæslu.

Tímalengd gjörgæsludvalar eftir kransæðahjáveitu er mismunandi og fer meðal annars eftir innlagnarástæðu, gangi skurðaðgerðar og hvort fylgikvillar koma upp eftir aðgerð. Í erlendum greinum hafa eftirtaldir áhættupættir lengdrar gjörgæsludvalar verið nefndir til sögunnar: hár aldur, skert útstreymisbrot (ejection fraction) vinstri slegils og langvinnir lungnasjúkdómar. ${ }^{2,3}$ Einnig

\section{Á G R I P}

\section{INNGANGUR}

Til að hámarka nýtingu gjörgæslurýma er mikilvægt að pekkja algengi og áhættupætti lengdrar dvalar á gjörgæsludeild eftir kransæðahjáveituaðgerð en slík rannsókn hefur ekki verið gerð áđur hér á landi.

\section{EFNIVIĐUR OG AĐFERĐIR}

Rannsóknin var afturskyggn og nádi til allra sjúklinga sem gengust undir kransæðahjáveituaðgerð á Landspítala á árunum 2001-2018. Skráđar voru upplýsingar um heilsufar sjúklinganna, að̌gerðartengda pætti og fylgikvilla eftir aðgerðina. Sjúklingar sem lágu á gjörgæslu i eina nótt voru bornir saman viơ pá sem lágu par tvær nætur eða lengur. Lifun var áætluð með aðferð Kaplan-Meiers. Forspárpættir dvalarlengdar á gjörgæslu voru fundnir með lógistískri aðhvarfsgreiningu og niðurstöðurnar notaðar til að útbúa reiknivél sem áætlar líkur á lengri gjörgæsludvöl.

\section{NIĐURSTÖĐUR}

Af 2177 sjúklingum burftu 20\% gjörgæsludvöl í tvær nætur eða lengur. Sjúklingar sem lágu tvær eða fleiri nætur á gjörgæslu voru oftar konur (23\% á móti 16\%, p=0,001). Pessir sjúklingar höfðu einnig oftar áhættupætti kransæðasjúkdóms og fyrri sögu um aðra hjartasjúkdóma eins og hjartabilun, lokusjúkdóma og skert útstreymisbrot vinstri slegils. Auk pess var EuroSCORE II gildi peirra hærra (4,7 á móti 1,9, p<0,001) og höfðu peir oftar skerta nýrnastarfsemi fyrir aðgerð (30\% á móti $16 \%, p<0,001)$ og purftu frekar á bráđaaðgerð að̛ halda ( $18 \%$ á móti $2 \%, p<0,001)$. Sjúklingar sem dvöldu tvær nætur eða lengur höfðu hærri tíðni skammog langtímafylgikvilla og verri langtímalifun en sjúklingar í viomiðunarhópi (78\% á móti $93 \%$ lifun 5 árum frá ađgerð, p<0,0001). Sjálfstæðir áhættupættir lengri gjörgæsludvalar voru aldur, kyn, EuroSCORE II gildi, fyrri saga um aðra hjartasjúkdóma, skert nýrnastarfsemi og bráđaađgerð.

\section{ÁLYKTANIR}

Fimmti hver sjúklingur parf gjörgæsludvöl i tvær eða fleiri nætur eftir kransæðahjáveitu á Landspítala. Ýmsir áhættupættir spá fyrir um lengri gjörgæsludvöl eftir kransæðahjáveitu, sérstaklega undirliggjandi ástand sjúklings, EuroSCORE II gildi og hve brátt aðgerðin fer fram. Von okkar er að bætt pekking á áhættu á lengri gjörgæsludvöl nýtist til að bæta skipulagningu kransæðahjáveituaðgerða á Landspítala.

geta fylgikvillar aðgerðar eins og skurðsýkingar, heilaáfall, takttruflanir, lungnabólga, hjartadrep í eða eftir aðgerð og gollurshússbólga lengt gjörgæsludvöl., ${ }^{3,4}$ Lengri dvöl á gjörgæslu tengist aukinni dánartíðni og verri langtímahorfum, ${ }^{2}$ en á hinn bóginn getur ótímabær útskrift af gjörgæsludeild aukið líkur á endurinnlögn á gjörgæslu, ${ }^{5}$ sem aftur tengist aukinni dánartíðni. ${ }^{6}$ 
Tafla I. Bakgrunnspættir. Meðaltal \pm staðalfrávik gefioð fyrir aldur, likamspyngdarstuðul og EuroSCORE II. Fjöldi (\%).

\begin{tabular}{|c|c|c|c|}
\hline & $\begin{array}{l}\text { Tvær eða } \\
\text { fleiri nætur á } \\
\text { gjörgæslu } \\
(\mathrm{n}=431)\end{array}$ & $\begin{array}{l}\text { Ein nótt á } \\
\text { gjörgæslu } \\
(n=1746)\end{array}$ & p-gildi \\
\hline Kvenkyn & $101(23)$ & $286(16)$ & 0,001 \\
\hline Aldur (ár) & $68( \pm 10)$ & $66( \pm 9)$ & $<0,001$ \\
\hline Líkamspyngdarstuðull (kg/m²) & $29( \pm 5)$ & $28( \pm 4)$ & 0,17 \\
\hline Nýlegt hjartaáfalla & $194(45)$ & $435(25)$ & $<0,001$ \\
\hline \multicolumn{4}{|l|}{ Fyrri saga um } \\
\hline Hjartabilun & $67(16)$ & $116(7)$ & $<0,001$ \\
\hline Eldra hjartaáfall & $133(31)$ & $386(22)$ & $<0,001$ \\
\hline Kransæðavíkkun ${ }^{\mathrm{b}}$ & $106(25)$ & $386(22)$ & 0,29 \\
\hline Takttruflanir & $69(16)$ & $175(10)$ & 0,001 \\
\hline Lokusjúkdómar & $38(9)$ & $36(2)$ & $<0,001$ \\
\hline Útæðasjúkdómur & $28(11)$ & $48(5)$ & $<0,001$ \\
\hline Skert nýrnastarfsemi & $129(30)$ & $283(16)$ & $<0,001$ \\
\hline Langvinn lungnateppa & $42(10)$ & $116(7)$ & 0,030 \\
\hline Útstreymisbrot $\leq 30 \%$ & $70(17)$ & $39(2)$ & $<0,001$ \\
\hline CCS-flokkur III/IV & $349(81)$ & $1235(71)$ & $<0,001$ \\
\hline NYHA-flokkur III/IV & $308(72)$ & $999(57)$ & $<0,001$ \\
\hline EuroSCORE II & $4,7( \pm 5,9)$ & $1,9( \pm 2,1)$ & $<0,001$ \\
\hline Dreifing kransæðasjúkdóms & & & 0,005 \\
\hline Einnar æðar sjúkdómur & $13(3)$ & $40(2)$ & \\
\hline Tveggja æð̌a sjúkdómur & $52(12)$ & $312(18)$ & \\
\hline Priggja æða sjúkdómur & $365(85)$ & $1394(80)$ & \\
\hline $\begin{array}{l}\text { Priggja æða sjúkdómur og/eða } \\
\text { vinstri höfuðstofnsprengsli }\end{array}$ & $393(91)$ & $1546(89)$ & 0,14 \\
\hline Bráđaaðgerð & $78(18)$ & $40(2)$ & $<0,001$ \\
\hline
\end{tabular}

aNýlegt hjartaáfall var skilgreint sem hjartaáfall innan síðustu 90 daga fyrir aðgerð. 'Kransæðavíkkun með eđa án stoðnetsísetningar.

Ýmis reiknilíkön hafa verið próuð til að greina hvaða sjúklingar eru í aukinni áhættu á að fá fylgikvilla sem krefjast lengri dvalar á gjörgæsludeild eftir hjartaaðgerðir.7 Parsonnet-líkanið (Parsonnet Score) og EuroSCORE spá vel fyrir um lengri dvöl eftir opna hjartaaðgerð, jafnvel pótt bæði líkönin hafi upprunalega verið próuð til að spá fyrir um líkur á dauða eftir hjartaaðgerð. ${ }^{7-9}$ Skilgreiningar á áhættubreytum og lengdri gjörgæsludvöl eru pó mismunandi og starfsemi gjörgæslu- og legudeilda eftir löndum afar ólík. Pví getur verið erfitt að yfirfæra niðurstöður úr einu sjúklingapýði yfir á annað.

Mikilvægt er að pekkja áhættupætti lengdrar gjörgæsludvalar eftir kransæðahjáveituaðgerð til að auðvelda skipulagningu á starfsemi á skurðstofu og gjörgæsludeildum. Engin slík spálíkön hafa pó áður verið próuð sérstaklega fyrir sjúklinga á Íslandi. Markmið pessarar rannsóknar var að kanna tíðni og áhættupætti fyrir lengri dvöl á gjörgæsludeild eftir kransæðahjáveituaðgerð á Landspítala og útbúa spálíkan til að meta líkur á lengdri legu á gjörgæsludeild.

\section{Efniviður og aðferðir}

Rannsóknin var afturskyggn og byggðist á gagnagrunni hjarta- og lungnaskurðdeildar Landspítala sem tók til peirra sjúklinga sem gengust undir sína fyrstu kransæðahjáveituaðgerð án annarrar hjartaaðgerðar (primary isolated CABG) frá 1. janúar 2001 til 31. desember 2018. Öll tilskilin leyfi lágu fyrir áður en rannsóknin hófst, meðal annars frá Persónuvernd, vísindasiðanefnd (VSN 10-099) og framkvæmdastjóra lækninga á Landspítala.

Sjúklingar voru fundnir með leit að aðgerðarnúmerum fyrir kransæðahjáveituaðgerð (FNSA00, FNSC10, FNSC20, FNSC30) og aðgerðum par sem hjarta- og lungnavél var notuð (FZSA00, FZSA10).

Skráning í gagnagrunninn hófst árið 2005 en síðan hefur skráning farið fram árlega. Í gagnagrunninum voru samtals 2177 sjúklingar sem var skipt í tvo hópa eftir dvalarlengd á gjörgæsludeild eftir kransæðahjáveituaðgerð. Annars vegar voru sjúklingar sem dvöldu tvær eða fleiri nætur á gjörgæsludeild $(\mathrm{n}=431)$ en hins vegar viðmiðunarhópur með sjúklingum sem dvöldu eina nótt á gjörgæsludeild ( $\mathrm{n}=1746)$.

Í gagnagrunninn voru skráðar grunnupplýsingar um sjúklingana, svo sem aldur, kyn, hæð, pyngd og líkamspyngdarstuðull (body mass index, BMI), en einnig upplýsingar um helstu áhættupætti kransæðasjúkdóms og fylgisjúkdóma hans á borð við hjartabilun, hjartadrep, hjartsláttaróreglu og lokusjúkdóma. Skráðar voru upplýsingar um aðra sjúkdóma sem tengjast aukinni áhættu á kransæðasjúkdómi eins og skerta nýrnastarfsemi (skilgreind sem gaukulsíunarhraði $<60 \mathrm{~mL} / \mathrm{mín} / 1,73 \mathrm{~m}^{2}$ fyrir aðgerð), langvinna lungnateppu og útæðasjúkdóm. Einkenni sjúklinganna voru stiguð með flokkun Canadian Cardiovascular Society (CCS) á hjartaöng og New York Heart Association (NYHA) sem metur alvarleika hjartabilunar. ${ }^{10,11}$ European System for Cardiac Operative Risk Evaluation-gildi (EuroSCORE II) var reiknað fyrir hvern sjúkling. ${ }^{12}$ Upplýsingar um útstreymisbrot í hjartaómun fyrir aðgerð var skráð. Skert útstreymisbrot vinstri slegils var skilgreint sem útstreymisbrot minna eða jafnt og 30\%. Par að auki voru skráð helstu lyf sem sjúklingarnir tóku fyrir aðgerð.

Færðar voru í gagnagrunninn upplýsingar um kransæðahjáveituaðgerðina sjálfa, meðal annars hvort aðgerðin var bráðaaðgerð (innan 24 klukkustunda frá innlögn), framkvæmd með flýtingu (í sömu innlögn) eða valaðgerð. Upplýsingar um aðgerðina, eins og tangartími, tími á hjarta- og lungnavél, fjöldi fjaræðatenginga (distal anastomoses) og notkun vinstri innri brjóstholsslagæðar (left internal mammary artery, LIMA) voru skráðar.

Upplýsingar um ástand sjúklinga eftir aðgerð voru skráðar í gagnagrunninn, meðal annars fjöldi daga á gjörgæsludeild og heildarlegutími á Landspítala. Snemmkomnir fylgikvillar eftir aðgerð voru skráðir og var peim skipt í minniháttar og alvarlega fylgikvilla. Til minniháttar fylgikvilla töldust nýtilkomið gáttatif (atrial fibrillation) eða gáttaflökt (atrial flutter), fleiðruvökvi sem parfnaðist aftöppunar, yfirborðssýking í skurðsári á ganglim eða yfir bringubeini, lungnabólga og pvagfærasýking. Мeðal alvarlegra fylgikvilla voru bringubeinslos (sternal dehiscence), djúp sýking í bringubeinsskurði, bráður nýrnaskaði sem krafðist blóðskilunar, heilablóðfall, blóðpurrð í hjartavöðva (perioperative myocardial infarction), fjöllíffærabilun og enduraðgerð vegna blæðingar. Í gagnagrunninn voru einnig skráðar upplýsingar um 
Mynd 1. Legutími sjúklinga sem lágu tvær eða fleiri nætur á gjörgæslu. Ekki er sýndur legutími 1746 sjúklinga sem lágu par i eina nótt.

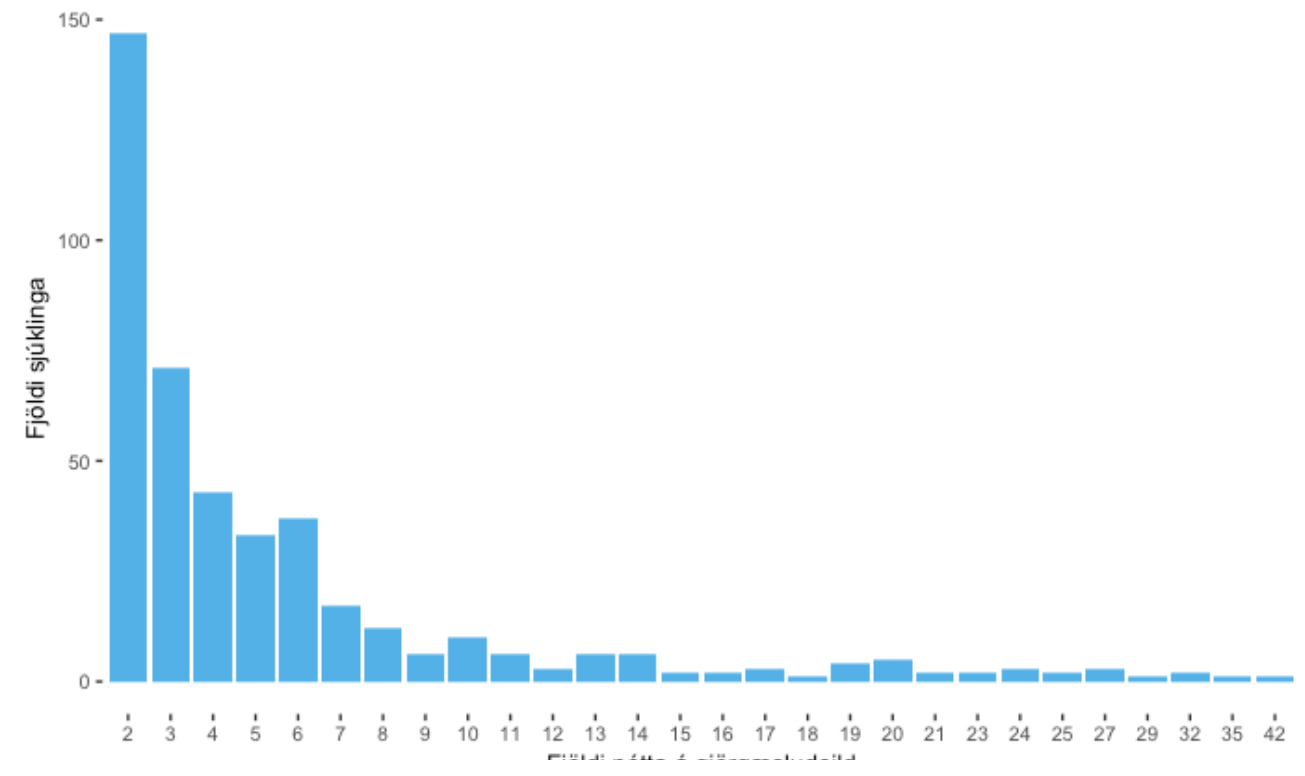

blæðingu í brjóstholskera fyrstu 24 klukkustundirnar eftir aðgerð og fjöldi eininga af rauðkornapykkni, blóðvökva og blóðflögum (platelets) sem voru gefnir í aðgerð eða fyrstu vikuna eftir aðgerð. Skráð var hverjir létust innan 30 daga frá aðgerð og í sjúkrahúslegu. Að lokum voru langtímafylgikvillar sem tengdust hjarta- og æðakerfinu skráðir en meðal peirra voru hjartaáfall, heilablóðfall, endurkransæðavíkkun (re-PCI), endurkransæðahjáveituaðgerð (re-CABG) og dauði. Pessar breytur voru teknar saman í sameiginlegan endapunkt sem kallast MACCE (major adverse cardiac and cerebrovascular event). Eftirfylgdartími lifunar var til 31. desember 2018 og var miðgildi eftirfylgdartímans 101,1 mánuður (bil: 0-215,9 mánuðir).

Breytur voru skráđar í rafræna Excel-skrá og tölfræðiúrvinnsla unnin í tölfræðiforritinu R, útgáfu 3.5.2, (R foundation for Statistical Computing, Austurríki) með RStudio, útgáfu 1.1.463. Fyrir flokkabreytur var notað kí-kvaðrat-próf en fyrir samfelldar breytur var t-próf notað til að bera saman hópana. Lifun var skoðuð með aðferð Kaplan-Meiers og samanburður milli hópa

\begin{tabular}{lccc}
\hline \multicolumn{4}{c}{ Tafla II. Lyfjanotkun fyrir aðgerð. Fjöldi (\%). } \\
\hline $\begin{array}{c}\text { Tvær eða fleiri } \\
\text { nætur á gjörgæslu } \\
(\mathrm{n}=431)\end{array}$ & $\begin{array}{c}\text { Ein nótt á } \\
\text { gjörgæslu } \\
(\mathrm{n}=1746)\end{array}$ & p-gildi \\
\hline Notkun blóðpynnandi eða blóðflöguhemjandi lyfja innan 5 daga fyrir aðgerð \\
\hline Aspirín & $214(55)$ & $774(48)$ & 0,039 \\
\hline Heparín & $203(51)$ & $731(45)$ & 0,047 \\
\hline Klópídógrel & $42(11)$ & $57(4)$ & $<0,001$ \\
\hline Warfarín & $1(0,25)$ & $7(0,43)$ & 0,94 \\
\hline Önnur lyf tekin innan 5 daga fyrir aðgerð & & 1,000 \\
\hline B-blokkar & $298(73)$ & $1216(73)$ & $<0,001$ \\
\hline Blóðfitulækkandi statín & $296(72)$ & $1358(80)$ & 0,66 \\
\hline Kalsíum-blokkar & $89(22)$ & $373(24)$ & \\
\hline
\end{tabular}

var gerður með log-rank prófi. Forspárpættir dvalarlengdar á gjörgæsludeild voru metnir með lógistískri aðhvarfsgreiningu. Inn í upphaflega líkanið voru settir peir pættir sem reyndust marktækir í einpátta greiningu auk ádurnefndra áhættupátta úr fyrri rannsóknum. Spágeta upphaflega líkansins var könnuð og viðeigandi breytur síðan teknar út með prepaðri aðhvarfsgreiningu par til endanlegt spálíkan fékkst fyrir lengdri dvöl á gjörgæsludeild. Tölfræðileg marktækni miðaðist við p-gildi <0,05.

\section{Niðurstöður}

Af 2177 sjúklingum dvaldi 431 tvær eða fleiri nætur á gjörgæslu, eða 20\% hópsins. Mynd 1 sýnir dreifingu dvalartíma meðal sjúklinga sem lágu tvær eða fleiri nætur á gjörgæslu. Langflestir peirra sem lágu tvær nætur eða lengur lágu par í tvær nætur (147 sjúklingar, 7\%), en 3\% lágu í prjár nætur og 10\% í fjórar eða lengur. Fyrir sjúklinga sem lágu tvær eða fleiri nætur var miðgildi legutíma á gjörgæslu prjár nætur (fjórðungabil: 2 - 6, bil 2 - 42).

Samanburð sjúklingahópanna tveggja má sjá í töflu I. Meðalaldur sjúklinga sem lágu tvær eða fleiri nætur á gjörgæslu var marktækt hærri (68 á móti 66 ár, p<0,001). Konur voru marktækt fleiri meðal peirra sem lágu par tvær eða fleiri nætur (23\% á móti $16 \%, p=0,001)$, og peir sjúklingar höfðu oftar sögu um hjartaáfall, hjartabilun, takttruflanir, lokusjúkdóma, útæðasjúkdóm, skerta nýrnastarfsemi, langvinna lungnateppu og skert útstreymisbrot vinstri slegils fyrir aðgerð (tafla I). Samanburður á helstu áhættupáttum kransæðasjúkdóms milli hópa sýndi marktækan mun á tíðni blóðfituröskunar (50\% á móti 58\%, p=0,004), sykursýki $(22 \%$ á móti 17\%, p=0,015) og fjölskyldusögu um kransæðasjúkdóm ( $46 \%$ á móti 54\%, p=0,007). Sjúklingar sem lágu tvær eða fleiri nætur á gjörgæslu höfðu meiri einkenni hjartaangar og alvarlegri einkenni hjartabilunar (tafla I) en höfðu auk pess hærra EuroSCORE II (4,7 á móti 1,9, p<0,001). Peir voru einnig líklegri til að purfa bráðaaðgerð (18\% á móti $2 \%, \mathrm{p}<0,001)$. 

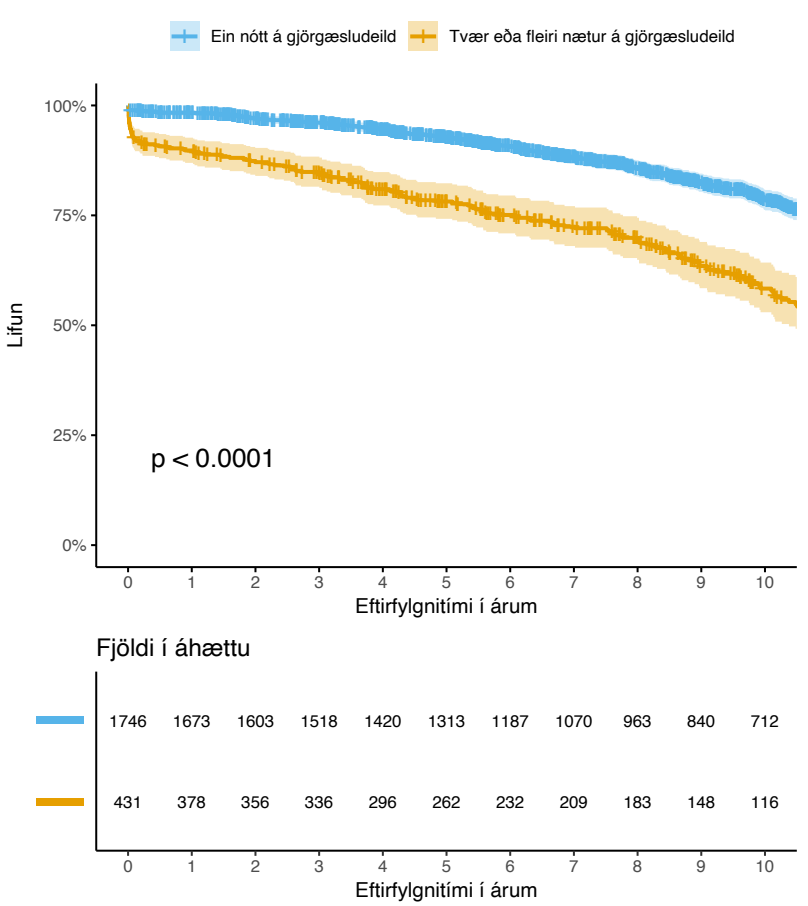

Mynd 2a. Heildarlifun (Kaplan-Meier) sjúklinga eftir dvalarlengd á gjörgæslu.

Samanburður á lyfjanotkun milli hópa fyrir aðgerð er sýndur í töflu II. Mestur munur var á notkun klópídógrels og blóðfitulækkandi statína. Peir sem lágu tvær eða fleiri nætur á gjörgæslu tóku oftar klópídógrel fyrir aðgerð (11\% á móti 4\%, p<0,001), en sjaldnar blóðfitulækkandi statín (72\% á móti 80\%, p<0,001).

\begin{tabular}{lccc}
\hline Tafla III. Snemmkomnir fylgikvillar eftir aðgerð. Fjöldi (\%). & & \\
\hline & $\begin{array}{c}\text { Tvær eða } \\
\text { fleiri nætur á } \\
\text { gjörgæslu } \\
(\mathrm{n}=431)\end{array}$ & $\begin{array}{c}\text { Ein nótt á } \\
\text { gjörgæslu } \\
(\mathrm{n}=1746)\end{array}$ & p-gildi \\
\hline Minniháttar fylgikvillar, samtals & $283(66)$ & $764(43)$ & $<0,001$ \\
\hline Sýking í skurðsári & $48(11)$ & $160(9)$ & 0,24 \\
\hline Nýtilkomið gáttatif/-flökt & $183(43)$ & $501(29)$ & $<0,001$ \\
\hline Aftöppun fleiðruvökva & $102(24)$ & $178(10)$ & $<0,001$ \\
\hline Lungnabólga & $77(18)$ & $61(4)$ & $<0,001$ \\
\hline Pvagfærasýking & $34(8)$ & $40(2)$ & $<0,001$ \\
\hline Alvarlegir fylgikvillar, samtals & $177(41)$ & $133(8)$ & $<0,001$ \\
\hline Bráður nýrnaskaði & $19(5)$ & $4(0,23)$ & $<0,001$ \\
\hline Miðmætisbólga & $14(3)$ & $6(0,34)$ & $<0,001$ \\
\hline Bringubeinslos & $23(5)$ & $9(0,52)$ & $<0,001$ \\
\hline Hjartadrep í eða eftir aðgerð & $39(9)$ & $43(2)$ & $<0,001$ \\
\hline Heilaáfall & $15(4)$ & $8(0,46)$ & $<0,001$ \\
\hline Fjöllíffærabilun & $56(13)$ & $6(0,34)$ & $<0,001$ \\
\hline Enduraðgerð vegna & $63(15)$ & $54(3)$ & $<0,001$ \\
\hline blæðingar & $31(7)$ & $19(1)$ & $<0,001$ \\
\hline 30-daga dánartíðni & & & \\
\hline & & & \\
\hline
\end{tabular}

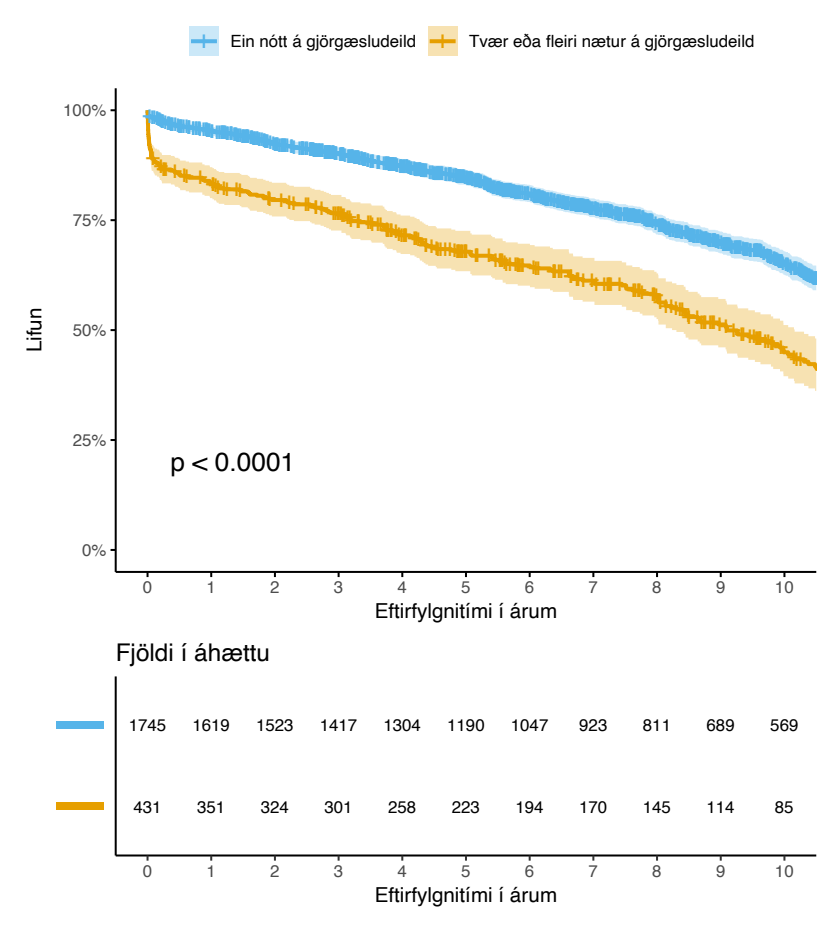

Mynd 2b. MACCE-frí lifun sjúkinga eftir dvalarlengd á gjörgæslu.

Vinstri brjóstholsslagæð (LIMA) var notuð hjá færri sjúklingum sem lágu tvær eða fleiri nætur á gjörgæslu (88\% á móti 96\%, $\mathrm{p}<0,001)$ og færri aðgerðir voru framkvæmdar á sláandi hjarta hjá peim $(12 \%$ á móti $17 \%, \mathrm{p}<0,001)$. Aðgerðartími peirra var lengri (234 mínútur á móti 209 mínútum, p<0,001), en einnig vélartími (105 mínútur á móti 89 mínútum, p<0,001), og tangartími (52 mínútur á móti 48 mínútum, $\mathrm{p}<0,001)$. Loks fengu peir oftar ósæðardælu (intra aortic balloon pump, IABP) í tengslum við aðgerðina (20\% á móti $0,7 \%, \mathrm{p}<0,001)$.

Einstaklingar sem dvöldu tvær eða fleiri nætur á gjörgæslu höfðu hærri tíðni minniháttar fylgikvilla (66\% á móti 43\%, p<0,001) (tafla III). Einnig reyndist marktækur munur á öllum alvarlegum fylgikvillum sem voru bornir saman milli hópanna. Sjúklingar sem purftu lengri gjörgæsludvöl purftu oftar á enduraðgerð að halda vegna mikillar blæðingar (15\% á móti 3\%, p<0,001) og 30-daga dánartíðni peirra var sjöfalt hærri borið saman við viðmiðunarhópinn (7\% á móti 1\%, p<0,001).

Langtímalifun og MACCE-frí lifun sjúklinga sem lágu tvær eða fleiri nætur á gjörgæslu var marktækt lakari en peirra sem lágu skemur á gjörgæslu (mynd 2). Pannig var eins árs lifun sjúklinga sem lágu í tvær eða fleiri nætur 90\% samanborið við 98\% í viðmiðunarhópnum $(\mathrm{p}<0,0001)$ en á sömu tímapunktum var MACCEfrí lifun $84 \%$ og 95\% ( $<<0,0001)$. Fimm ára lifun sjúklinga sem lágu tvær eða fleiri nætur var 78\% samanborið við 93\% í viðmiðunarhópnum $(\mathrm{p}<0,0001)$. Á sama tíma var MACCE-frí lifun pessara hópa $68 \%$ og $85 \%$ ( $\mathrm{p}<0,0001)$.

Samkvæmt fjölpátta aðhvarfsgreiningu voru helstu sjálfstæðu áhættupættirnir fyrir lengri dvöl á gjörgæslu sem pekktir voru fyrir aðgerð hærri aldur, kvenkyn, hærra EuroSCORE II gildi, skert nýrnastarfsemi, pörf á bráðaaðgerð og fyrri saga um aðra hjartasjúkdóma eins og hjartabilun og lokusjúkdóma (tafla IV). 


\begin{tabular}{|c|c|c|}
\hline & Óleiðrétt GH (95\% ÖB) & Leiðrétt GH (95\% ÖB) \\
\hline Kyn (kvenkyn) & $1,56(1,21-2,01)$ & $1,50(1,07-2,07)$ \\
\hline Aldur (ár) & $1,02(1,01-1,04)$ & $1,01(0,99-1,02)$ \\
\hline Nýlegt hjartaáfall & $2,47(1,98-3,07)$ & $1,23(0,91-1,65)$ \\
\hline Saga um hjartaáfall & $1,57(1,24-1,98)$ & \\
\hline Saga um hjartabilun & $2,59(1,87-3,57)$ & $1,89(1,23-2,85)$ \\
\hline Saga um takttruflanir & $1,72(1,26-2,31)$ & \\
\hline Lokusjúkdómar & $4,60(2,88-7,37)$ & $3,66(1,98-6,73)$ \\
\hline Útæðasjúkdómur & $2,56(1,55-4,14)$ & \\
\hline Skert nýrnastarfsemi & $2,23(1,74-2,83)$ & $1,18(0,85-1,61)$ \\
\hline Langvinn lungnateppa & $1,53(1,05-2,20)$ & \\
\hline Útstreymisbrot <30\% & $8,68(5,80-13,2)$ & $5,05(2,95-8,70)$ \\
\hline CCS-flokkur III/IV & $1,76(1,36-2,30)$ & \\
\hline NYHA-flokkur III/IV & $1,87(1,49-2,36)$ & \\
\hline EuroSCORE II & $1,29(1,24-1,35)$ & $1,11(1,05-1,18)$ \\
\hline Bráđaaðgerð & $9,42(6,37-14,1)$ & $5,19(2,93-9,26)$ \\
\hline Blóðfituröskuna & $0,72(0,58-0,90)$ & \\
\hline Sykursýki & $1,40(1,07-1,81)$ & \\
\hline $\begin{array}{l}\text { Fjölskyldusaga um } \\
\text { kransæðasjúkdóm }\end{array}$ & $0,74(0,59-0,92)$ & \\
\hline Klópídógrel & $3,22(2,12-4,86)$ & \\
\hline Aspirín & $1,27(1,02-1,58)$ & \\
\hline Heparín & $1,26(1,01-1,57)$ & \\
\hline Statín & $0,64(0,50-0,82)$ & \\
\hline
\end{tabular}

aUpplýsingar um blóđfituröskun voru fengnar úr rafrænni sjúkraskrá (Sögu) á Landspítala.

Eftir fjölbreytuleiðréttingu reyndust aldur, nýlegt hjartaáfall og skert nýrnastarfsemi hins vegar ekki lengur spá fyrir lengri dvöl á gjörgæslu. Pví var í lokalíkaninu leiðrétt fyrir kyni, aldri, nýlegu hjartaáfalli, sögu um hjartabilun, lokusjúkdómi, skertri nýrnastarfsemi, vinstra slegils útstreymisbroti $30 \%$ eða undir, EuroSCORE II gildi og hvort aðgerðin var bráðaaðgerð (tafla IV). Út frá niðurstöðum fjölpátta aðhvarfsgreiningar var útbúinn áhættureiknir sem hægt er að nota til að áætla líkur á pví að sjúklingur liggi tvær eða fleiri nætur á gjörgæsludeild eftir kransæðahjáveitu á Landspítala. Reiknivélina má finna á eftirfarandi vefslóð: https://notendur.hi.is/ mingi/calculator.html (mynd 3).

\section{Umræður}

Tuttugu prósent sjúklinga sem gengust undir kransæðahjáveituaðgerð á Landspítala á árunum 2001-2018 dvöldu tvær eða fleiri nætur á gjörgæslu. Pættir sem spáðu fyrir um lengri dvöl á gjörgæslu tengdust flestir verra heilsufari sjúklings en einnig töku ákveðinna lyfja og háu EuroSCORE II gildi. Í erlendum rannsóknum var hlutfall sjúklinga sem lágu tvær eða fleiri nætur á gjörgæslu eftir hjáveituaðgerð mjög breytilegt. ${ }^{2,13}$ Samanburður er pó oft erfiður pví par var grunnbreytan, pað er lengd gjörgæsludvalar, oft miðuð við aðra tímalengd en í okkar rannsókn. Í rann-

\section{Likelihood of prolonged ICU stay (two nights or more) following CABG}

This calculator estimates the likelihood of prolonged ICU stay (two nights or more) in patients undergoing CABG at Landspitali

\section{Risk factors}

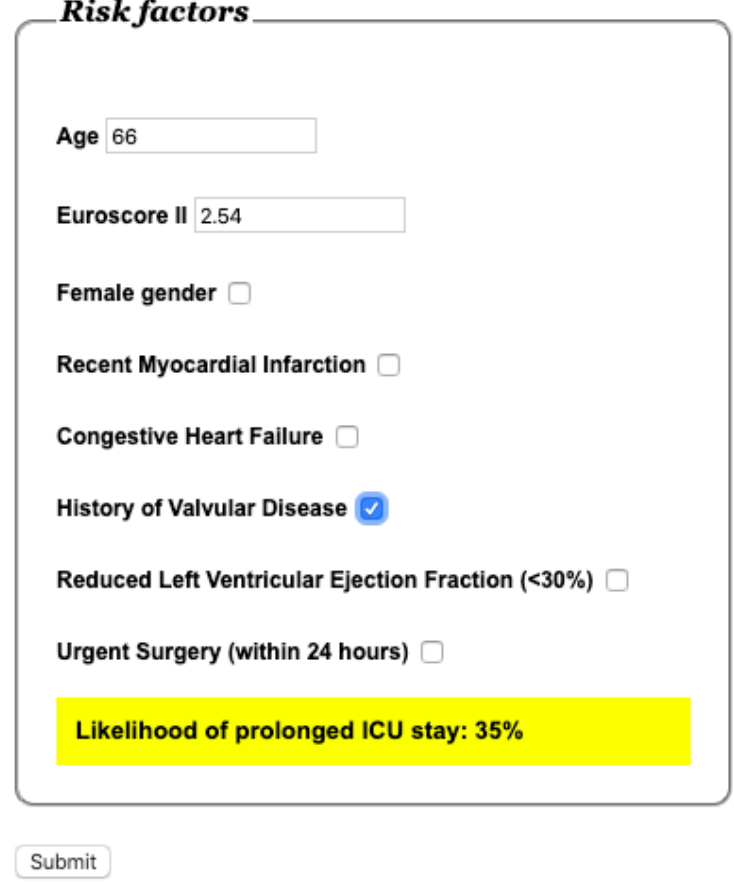

Mynd 3. Dæmi um niðurstöður úr vefreiknivél sem metur líkur á að sjúklingur liggi tvær eða fleiri nætur á gjörgæsludeild eftir kransæðahjáveituaðgerð á Landspítala. Reiknivélina má finna hér: https://notendur.hi.is/mingi/calculator.html.

sókn Azarfarin og félaga lágu til dæmis 34\% sjúklinga lengur en 96 klukkustundir á gjörgæslu eftir opna hjartaaðgerð. ${ }^{2}$ Mögulega hefur legutími á gjörgæslu lengst í einhverjum tilvikum pegar ekki var hægt að taka á móti sjúklingum á legudeild vegna plássleysis. Ennfremur er hugsanlegt að útskriftum af gjörgæsludeild hafi verið flýtt vegna bráðveikra eða slasaðra einstaklinga sem purftu frekar á gjörgæslueftirliti að halda, sem gæti hafa skekkt niðurstöðurnar.

Peir pættir sem fylgdu lengri dvöl á gjörgæslu voru flestir tengdir verra heilsufari sjúklings. Einnig sást munur á EuroSCORE II áhættuskori og lyfjatöku. Áhugavert er að blóðfitulækkandi statín virðast vera verndandi páttur fyrir lengri gjörgæsludvöl í okkar rannsókn. Petta tengist líklega pví að sjúklingar sem gangast undir bráđaaðgerð eru síður líklegir til að hafa pekktan kransæðasjúkdóm og taka blóðfitulækkandi lyf, en sjúklingar sem undirgangast bráðaaðgerð eru í aukinni áhættu á að purfa lengri en tvær nætur á gjörgæsludeild.

Út frá peim breytum sem pekktar voru fyrir aðgerð var útbúið spálíkan til að reikna líkur á dvalarlengd á gjörgæslu í tvær eða fleiri nætur. Margar af breytunum í spálíkaninu eru sambærilegar erlendum rannsóknum, eins og aldur, kyn og hjartabilunareinkenni. ${ }^{2-4,14}$ Samkvæmt erlendum rannsóknum er pekkt að áhættupættir eins og hár aldur, minnkað útstreymisbrot, og lungna- 
sjúkdómar hafa tengsl við lengda gjörgæsludvöl. ${ }^{14}$ Pó reyndust lungnasjúkdómar ekki hafa jafn mikil áhrif í okkar rannsókn og peim erlendu.

Marktækt færri aðgerðir voru framkvæmdar á sláandi hjarta hjá sjúklingum sem lágu tvær eða fleiri nætur á gjörgæslu. Jafnframt var notkun á vinstri brjóstholsslagæð (LIMA) fátíðari hjá pessum sjúklingum, sem er í samræmi við niðurstöður annarra rannsókna. ${ }^{15}$ Petta má sennilega útskýra með peirri staðreynd að notkun LIMA-græðlings lengir aðgerðartíma og eykur blæðingarhættu og bráðveikir sjúklingar pola síður aðgerð á sláandi hjarta. Loks er líklegt að sjúklingar sem dvelja lengur á gjörgæsludeild séu veikari fyrir aðgerð, sem stýrir ákvörðuninni að nota ekki LIMA-græðling eða gera aðgerðina á sláandi hjarta.

Marktækur munur var á næstum öllum minniháttar og alvarlegum fylgikvillum milli hópanna, en svipuðum niðurstöðum hefur verið lýst erlendis. ${ }^{15-17}$ Enduraðgerðir vegna blæðingar voru marktækt fleiri hjá sjúklingum sem voru tvær eða fleiri næutur á gjörgæslu samanborið við pá sem lágu par í eina nótt, en sýnt hefur verið fram á tengsl enduraðgerða vegna blæðingar við lengri gjörgæsludvöl. ${ }^{16}$ Prjátíu daga dánartíðni var marktækt hærri hjá peim sem lágu tvær eða fleiri nætur á gjörgæslu og er í samræmi við fjölda sambærilegra rannsókna erlendis. ${ }^{4,15,17}$ Einnig reyndist marktækur munur á langtímalifun milli hópanna tveggja og munaði $8 \%$ ári frá aðgerð og $15 \%$ eftir 5 ár $(\mathrm{p}<0,0001)$. Tvær erlendar rannsóknir sýndu sömuleiðis marktækt verri eins árs lifun hjá einstaklingum með lengri gjörgæsludvöl líkt og í okkar rannsókn. ${ }^{18,19}$ Rannsókn Williams og félaga sýndi einnig marktækan mun eftir 5 og 10 ár. ${ }^{20}$ Svipaður munur sást fyrir MACCE-fría lifun $(p<0,0001)$ og var pað einnig sambærilegt og í öðrum erlendum rannsóknum. ${ }^{21}$

Helsti styrkleiki pessarar rannsóknar er að margar breytur voru skráðar fyrir hvern sjúkling og er gagnagrunnurinn pví mjög ítarlegur. Auk pess lágu upplýsingar um legutíma á sjúkrahúsi fyrir hjá nær öllum sjúklingum og eftirfylgd sjúklinganna með tilliti til lifunar var nánast 100\%. Loks er sjúklingahópurinn til- tölulega einsleitur, allir sjúklingar fóru í aðgerð í sömu stofnun og voru meðhöndlaðir af fáum skurðlæknum og gjörgæslulæknum. Rannsóknartímabilið var langt og ljóst að breytingar hafa orðið á aðgerðarábendingum, aðgerðartækni, sjúklingahópi og starfsemi gjörgæsludeildar Landspítala á tímabilinu. Pannig er mögulegt að samsetning sjúkingahópsins með tilliti til áhættupátta og einnig samsetning áhættupátta með tilliti til lengdrar dvalar á gjörgæslu hafi breyst á rannsóknartímabilinu. Petta gæti valdið pví að forspárpættir gætu verið ýmist ofmetnir eða vanmetnir. Gildi reiknisins verður pví að kanna betur framskyggnt. Helsti veikleiki rannsóknarinnar er afturskyggn hönnun hennar. Sömuleiðis töldum við fjölda sjúklinga ekki nægan til að skipta pýðinu upp til að búa til hönnunar- og prófunarpýði fyrir áhættureikninn, en stefnan er að kanna reikninn framskyggnt.

Niðurstöður pessarar rannsóknar sýna að fimmti hver sjúklingur parf gjörgæsludvöl í tvær eða fleiri nætur eftir kransæðahjáveitu á Landspítala. Ýmsir áhættupættir spá fyrir um lengri gjörgæsludvöl eftir kransæðahjáveitu, sérstaklega undirliggjandi ástand sjúklings, hærra EuroSCORE II og hve brátt aðgerðin fer fram. Á Íslandi eru ekki til svokallaðar hágæsludeildir sem eru millistig milli gjörgæsludeildar og almennrar legudeildar, en par liggja sjúklingar sem purfa mikla umönnun og eftirlit en parfnast ekki fullrar gjörgæslumeðferðar. Ef slíkur möguleiki væri til staðar á Landspítala gæti pað hugsanlega létt á gjörgæsludeildinni og aukið möguleika á valaðgerðum eins og kransæðahjáveituaðgerðum. Með betri skilningi á áhættupáttum lengdrar gjörgæsludvalar vonumst við til pess að unnt verði að skipuleggja valaðgerðir betur til að hámarka nýtingu gjörgæsluplássa, og draga úr frestun valaðgerða sem krefjast gjörgæsluinnlagna.

\section{Pakkir}

Pakkir fá læknar á hjarta- og lungnaskurðdeild og gjörgæsludeild Landspítala. Rannsóknin var styrkt af Vísindasjóði Landspítala og Rannsóknasjóði Háskóla Íslands. 


\section{Heimildir}

1. Kárason S. Tólf gjörgæslurúm á Landspítala - dugar pað til? Læknablaðið 2018; 104: 333

2. Azarfarin $\mathrm{R}$, Ashouri $\mathrm{N}$, Totonchi $\mathrm{Z}$, Bakhshandeh $\mathrm{H}_{\text {, }}$ Yaghoubi A. Factors influencing prolonged ICU stay after open heart surgery. Res Cardiovasc Med 2014; 3: e20159.

3. Legare JF, Hirsch GM, Buth KJ, MacDougall C, Sullivan JA. Preoperative prediction of prolonged mechanical ventilation following coronary artery bypass grafting. Eur J Cardiothorac Surg 2001; 20: 930-6.

4. Weintraub WS, Jones EL, Craver J, Guyton R, Cohen C. Determinants of prolonged length of hospital stay after coronary bypass surgery. Circulation 1989; 80: 276-84

5. Lazar HL, Fitzgerald CA, Ahmad T, Bao Y, Colton T, Shapira OM, et al. Early discharge after coronary artery bypass graft surgery: are patients really going home earlier? J Thorac Cardiovasc Surg 2001; 121: 943-50.

6. Cohn WE, Sellke FW, Sirois C, Lisbon A, Johnson RG Surgical ICU recidivism after cardiac operations. Chest 1999; 116: 688-92.

7. Ettema RGA, Peelen LM, Schuurmans MJ, Nierich AP, Kalkman CJ, Moons KGM. Prediction Models for Prolonged Intensive Care Unit Stay After Cardiac Surgery. Circulation 2010; 122: 682-9.
8. De Maria R, Mazzoni M, Parolini M, Gregori D, Bortone F, Arena V, et al. Predictive value of EuroSCORE on long term outcome in cardiac surgery patients: a single institution study. Heart 2005; 91: 779-84.

9. Lawrence DR, Valencia O, Smith EE, Murday A, Treasure T. Parsonnet score is a good predictor of the duration of intensive care unit stay following cardiac surgery. Heart 2000; 83: 429-32

10. Campeau L. Letter: Grading of angina pectoris. Circulation 1976; 54: 522-3.

11. Criteria Committee of the New York Heart Association. Nomenclature and Criteria for Diagnosis of Diseases of the Heart and Great Vessels. 9th ed. Little, Brown, Boston 1994.

12. EuroSCORE Study Group. EuroSCORE II calculator 2011 euroscore.org/calc.html - nóvember 2019.

13. Hughes M, MacKirdy FN, Norrie J, Grant IS. Outcome of long-stay intensive care patients. Intensive Care Med 2001; 27: 779-82.

14. Gruenberg DA, Shelton W, Rose SL, Rutter AE, Socaris $\mathrm{S}$, McGee G. Factors Influencing Length of Stay in the Intensive Care Unit. Am J Crit Care 2006; 15: 502-9.

15. Herman C, Karolak W, Yip AM, Buth KJ, Hassan A, Legare JF. Predicting prolonged intensive care unit length of stay in patients undergoing coronary artery bypass surgery--development of an entirely preoperative scorecard. Interact Cardiovasc Thorac Surg 2009; 9: 654-8.
16. Ngufor C, Murphree D, Upadhyaya S, Madde N, Pathak J, Carter R, et al. Predicting Prolonged Stay in the ICU Attributable to Bleeding in Patients Offered Plasma Transfusion. AMIA Annu Symp Proc 2017 2016: 954-63.

17. Yu PJ, Cassiere HA, Fishbein J, Esposito RA, Hartman AR. Outcomes of Patients With Prolonged Intensive Care Unit Length of Stay After Cardiac Surgery. J Cardiothorac Vasc Anesth 2016; 30: 1550-4.

18. Laupland KB, Kirkpatrick AW, Kortbeek JB, Zuege DJ. Long-term mortality outcome associated with prolonged admission to the ICU. Chest 2006; 129: 954-9.

19. Steenbergen $S$, Rijkenberg $S$, Adonis $T$, Kroeze $G$, van Stijn I, Endeman H. Long-term treated intensive care patients outcomes: the one-year mortality rate, quality of life, health care use and long-term complications as reported by general practitioners. BMC Anesthesiol 2015; 15: 142.

20. Williams TA, Ho KM, Dobb GJ, Finn JC, Knuiman M, Webb SA. Effect of length of stay in intensive care unit on hospital and long-term mortality of critically ill adult patients. Brit J Anaesth 2010; 104: 459-64.

21. Diab MS, Bilkhu R, Soppa G, Edsell M, Fletcher $\mathrm{N}$, Heiberg J, et al. The influence of prolonged intensive care stay on quality of life, recovery, and clinical outcomes following cardiac surgery: A prospective cohort study. J Thorac Cardiovasc Surg 2018; 156: 1906-15.e3.

\section{Incidence and predictors of prolonged intensive care unit stay after coronary artery bypass in Iceland}

\author{
Erla Liu Ting Gunnarsdóttir \\ Sunna Lu Xi Gunnarsdóttir ${ }^{1}$ \\ Alexandra Aldís Heimisdóttir ${ }^{1}$ \\ Sunna Rún Heiðarsdóttir ${ }^{1}$ \\ Sólveig Helgadóttir ${ }^{2}$ \\ Tómas Guðbjartsson ${ }^{1,3}$ \\ Martin Ingi Sigurðsson ${ }^{1,4}$
}

Introduction: To maximize the use of intensive care unit (ICU) resources, it is important to estimate the prevalence and risk factors for prolonged ICU unit stay after coronary artery bypass grafting (CABG) surgery.

Material and methods: This retrospective cohort study included all patients who underwent primary isolated CABG at Landspitali between 2001 and 2018. Patient information was collected from hospital charts and death registries. Patients who stayed in the ICU for the conventional one night postoperatively were compared with those who needed longer stays in the ICU. Survival rate was estimated with the Kaplan-Meier method. Predictors for prolonged ICU stay were calculated with logistic regression and the outcome used to create a calculator that estimates the probability of prolonged ICU stay.

Results: Out of 2177 patients, $20 \%$ required prolonged ICU stay. Patients with prolonged stay were more frequently female $(23 \%$ vs
$16 \%, p=0.001$ ), had a higher rate of cardiovascular risk factors and higher EuroSCORE II (4.7 vs. $1.9, p<0.001)$. They also had a higher rate of impaired renal function before surgery $(14 \%$ vs. $4 \%, p<0.001)$ and emergent surgery $(18 \%$ vs. $2 \%, p<0.001)$. Furthermore, these patients had higher rates of both short-term and long-term complications, and lower long-term survival ( $85 \%$ vs $68 \%$ five-year survival rate, $p<0.0001$ ). Independent risk factors for prolonged ICU stay were advanced age, female gender, EuroSCORE II, history of heart diseases, impaired renal function and emergent surgery. Conclusions: Every fifth patient had a prolonged ICU stay after CABG. Several risk factors predicted prolonged ICU stay after CABG, in particular patients' medical condition before surgery, EuroSCORE II and emergent surgery. A better understanding of the risk factors for prolonged ICU stay will hopefully aid in scheduling CABG surgeries at Landspitali.

${ }^{1}$ Faculty of Medicine, University of Iceland, ${ }^{2}$ Department of Anesthesia and Intensive Care, Akademiska University Hospital, Uppsala, Sweden, Departments of ${ }^{3} \mathrm{Cardiothoracic} \mathrm{Surgery}$ and ${ }^{4}$ Anesthesia and Intensive Care, Landspitali University Hospital, Reykjavik, Iceland.

Key words: Coronary artery bypass grafting, CABG, Intensive care unit, length of stay, 30 day mortality, complications, outcome.

Correspondence: Martin Ingi Sigurðsson, martiningi@gmail.com 